удк 343(571.53)(09)

А. А. Сысоев

Восточно-Сибирский институт МВД России, г. Иркутск, Российская Федераиия

Д. Б. Кавецкий

Восточно-Сибирский институт МВД России, 2. Иркутск, Российская Федерация

\title{
УСТОЙЧИВЫЕ ПРЕСТУПНЫЕ ГРУППЫ И ИХ ПРЕСЛЕДОВАНИЕ НА ТЕРРИТОРИИ ИРКУТСКОЙ ГУБЕРНИИ В ХІХ СТОЛЕТИИ
}

\begin{abstract}
АНнотАция. Специфика географического положения Иркутской губернии, административное и экономическое значение региона предопределили повышенную криминальную активность его населения. Уже в XIX столетии отличительными чертами Прибайкалья считались чрезвычайно высокий уровень уголовной преступности и недостаточно эффективная система обеспечения личной и имущественной безопасности ее жителей. В работе рассматриваются обстоятельства, сопутствовавшие данному явлению, и причины его возникновения. При этом авторами выявлены основные способы борьбы с проявлениями преступности на территории региона. Раскрыты региональные особенности, способствовавшие формированию сплоченных преступных групп и препятствующие эффективному пресечению их противоправной деятельности. В исследовании используются публикаций местной и центральной прессы XIX в., юридические акты и значительный массив ранее не использованных архивных материалов. Достаточная репрезентативность источниковой базы позволяет установить с известной долей достоверности обстоятельства сопутствующие формированию устойчивых преступных групп.

кЛючЕВЫЕ СЛОВА. Полиция; преступность; разбой; убийства; Сибирь; Иркутская губерния.

ИНФОРМАЦИЯ О СТАТЬЕ. Дата поступления 20 апреля 2017 г.; дата принятия к печати 17 мая 2017 г.; дата онлайн-размещения 16 июня 2017 г.
\end{abstract}

A. A. Sysoyev

East-Siberian Institute of the MIA of Russia, Irkutsk, Russian Federation

D. B. Kavetsky

East-Siberian Institute of the MIA of Russia, Irkutsk, Russian Federation

\section{STABLE CRIMINAL GROUPS AND THEIR PURSUIT ON THE TERRITORY OF IRKUTSK PROVINCE IN THE XIX CENTURY}

ABSTRACT. Specificity of the geographical position of Irkutsk Province, the administrative and economic significance the region determined an increased criminal activity of its population. Already in the nineteenth century of distinctive features of the Baikal Region were an extremely high level of criminality and lack of effective system of ensuring personal and property safety of its residents. The paper examines the circumstances accompanying this phenomenon and the cause of its occurrence. In this case, the authors identify the main ways of combating criminal manifestations in the region's territory. They reveal the regional features that contribute to formation of united criminal groups and prevent from effective suppression of their illegal activities. The study uses publications in local and national press of the $19^{\text {th }}$ century, legal acts and a significant array of previously unused archival materials. An adequate representation of the source base allows to identify the circumstances accompanying formation of stable criminal groups with a bit of certainty.

KEYWORDS. Police; criminality; robbery; murder; Siberia; Irkutsk Province.

ARTICLE INFO. Received April 20, 2017; accepted May 17, 2017; available online June 16, 2017.

(ㄷ) А. А. Сысоев, Д. Б. Кавещкий, 2017

\section{Baikal Research Journal}


Дореформенная Сибирь представлялась современникам страной полной потенциальных возможностей и соблазнов. Оживленные торговые пути и несметные природные богатства притягивали легких на подъем людей, всевозможных авантюристов и ...профессиональных преступников.

Появлению последних во многом способствовала окраинная политика самодержавия [1, с. 275]. Ссылка и каторга наводняли сибирские просторы людьми осужденными обществом и государством за различные правонарушения. Особенности же организации отечественной пенитенциарной системы позволяли значительной их части избегать наказания, скрываясь с мест принудительного содержания [2, с. 223].

Положение усугублялось крайне слабой постановкой розыскного дела. «Благодаря почти полному отсутствию розыска, - констатировал прокурор Иркутской судебной палаты, большое число совершаемых преступлений и при том самого тяжелого характера оставались не раскрытыми».

Поясняя причины неудовлетворительного состояния сыскной части, прокурор указывал на «малочисленность полицейских чинов по сравнению с обширностью принадлежащих им районов и количеством входящего в этот район населения» ${ }^{1}$ На каждый из 25 станов Иркутской губернии приходилось только по одному становому приставу и по два-три урядника. Средняя же площадь одного стана (29 685 кв. верст) превышала площадь всей Московской губернии (29 263 кв. версты).

При этом, значительная часть местного населения имела самое прямое и непосредственное отношение к криминальному миру. «Большую часть жителей уезда составляет ссыльный элемент, потомки ссыльных и разные подонки общества, высланные как вредные элементы из Европейской России», - сообщал по этому поводу губернскому руководству исправник Нижнеудинского уезда ${ }^{2}$.

Массовое перемещение наиболее опасных представителей российского общества к восточным окраинам Империи при отсутствии должного полицейского надзора вело к появлению значительного количества сплоченных преступных групп.

Первые упоминания об объединении преступников в устойчивые группы на территории Иркутской губернии или как их тогда называли - разбойничьи шайки, относятся к концу XVIII столетия.

По сведениям одного из первых бытописателей провинциальной жизни И. Т. Калашникова, «в окрестностях Иркутска не было безопасно... в темных лесах, покрывавших Верхоленскую гору и ее подошву гнездились разбойники, нападали на проезжих грабили, убивали».

В нескольких десятках верст от города находились три завода, на которых работали каторжане - два винокуренных один соляной. Охрану заводов составляли казаки и военные инвалиды. «Когда каторжным надоедало работать, они преспокойно подходили к инвалидам, брали у них ружья и шли, куда им заблагорассудилось. Таким образом, - по мнению писателя, составлялись большие шайки, и любимым их притоном была Верхоленская гора, заросшая дремучим лесом, и недалеко от города: два необходимых условия разбойничьего промысла».

И. Т. Калашников описывает случай когда, «разбойники убили до семи человек крестьян, возвращавшихся из города. Быв без оружия, крестьяне вывернули из телег оглобли и защищались храбро; но разбойники вооруженные ружьями и ножами, одолели и убили всех до единого» [3, с. 202].

По сообщениям иркутских летописей, «в феврале 1799 г. с Тельминской фабрики убежало 12 человек ссыльных, которые за тем ворвались в дом крестьянина Емельяна Быкова, убили его и перерезали все его семейство» [4, с. 151]. Осо-

${ }^{1}$ Государственный архив Иркутской области (ГАИО). Ф. 25. ОП. 10. Д. 114. Л. 45.

${ }^{2}$ ГАИО. Ф. 32. ОП. 34. Д. 18. Л. 10.

\section{Baikal Research Journal}

электронный научный журнал Байкальского государственного университета 
бенную же «славу» тогда приобрела шайка бывшего офицера Баратоева. В один из набегов разбойникам удалось захватить город Жћиганск [5, с. 215].

В стремлении искоренить преступный промысел губернские власти предпринимали чрезвычайные меры. В местах ожидаемого появления разбойников выставлялись пикеты из казаков. С ведома иркутского гражданского губернатора действительного статского советника Николая Ивановича Трескина практиковались наказания в 300 ударов кнутом. По рассказам очевидцев тех событий, «никто не мог перенести подобного истязания... однажды было засечено подобным образом четырнадцать человек» [3, с. 202].

К 20-м гг. XIX столетия положение дел ухудшилось настолько, что, по свидетельству современников, даже в столице Восточной Сибири - Иркутске не было «ни малейшей безопасности» от воров, грабителей и убийц, которые имели в городе «первое и надежное гнездилище» [1, с. 118].

Соответствующими были и меры, направленные на пресечение деятельности преступников. Так в исторической литературе описываются факты внесудебной расправы местных властей над наиболее грозными представителями преступного мира.

В частности, по сведениям Иркутского губернского воинского начальника В. К. Андриевича, при генерал-губернаторе А. С. Лавинском был засечен без решения суда на смерть один из атаманов разбойничьих шаек Александров.

Из рассказа очевидца тех событий горного чиновника И. Я. Козлова известно что, «бывший ярославский мещанин Александров силы был необыкновенной, бегал так скоро, что веревка в пять сажен, привязанная к затылку, при беге Александрова - держалась горизонтально. Стрелял на бегу без промаха. Данному слову Александров никогда не изменял. Шайка его никогда не превышала 7 или 8-ми человек, но были и постоянные: есаул, лейтенант и подручный. Это были люди испытанные им. Один раз, убежав из Иркутского острога, он на глазах у чинов полиции, будучи в кандалах, переплыл через Ангару» [6, с. 80].

Однако осенью 1822 (?) г. Александрова задержали около Александровского солеваренного завода в 60 верстах от Иркутска. Управляющий заводом И. Я. Козлов посадил разбойника на 4 дня в «скрипку» ${ }^{3}$.

За жестокое наказание Александров поклялся убить горного чиновника. Управляющий заводом, в свою очередь, доложил об этом генерал-губернатору. А. С. Лавинский, ознакомившись с материалами следственного дела о разбойничьей шайке, оставил на последней странице резолюцию: «Четырех главных наказать кнутом нещадно».

Вот как описывается расправа над именитым разбойником и его подручными: «В назначенный день преступников вывели из острога, как бы для допроса в земский суд, но по дороге, у мясного рынка, где жил палач Буянов, их остановили и объявили решение генерал-губернатора. Александров протестовал, ссылаясь на незаконность приговора, потому что не было окончено следствие. Шестеро прислужников Буянова привязали разбойника к кобыле ремнями. После первого удара Александров повернулся так, что лопнули ремни и, махнув кандалами, задел Буянова за плечо, разорвал на нем плисовую куртку, а сам бросился бежать; уже бежал по базарной площади к Ангаре, бежал в ножных кандалах, а солдаты не могли догнать его; бежал и на обе стороны махал ручными кандалами, народ расступался. Не заметил атаман колышка, к которому привязывают приезжие крестьяне лошадей; за колышек зацепил ножными кандалами и упал, солдаты набежали и прикладами прибили его. Привязали вновь к кобыле, атаман мол-

\footnotetext{
${ }^{3}$ Две широкие доски, сбитые вместе с отверстиями для рук и шеи - авт.
}

\section{Baikal Research Journal}


чал; после четвертого удара Буянов за волосы поднял голову и сказал: «уберите»! Александров был мертв» [7, с. 326].

Примечательно, что, несмотря на практику внесудебной расправы и жестокие наказания, спустя 12 лет после описываемых событий, по сведениям посетившего Иркутск жандармского штаб-офицера Э. И. Стогова, «жизнь в городе была [по прежнему] мало обеспечена, частые убийства, грабежи, воровства... не далеко от Иркутска в горах [действовало] две шайки разбойников» ${ }^{4}$.

«При мне и на моих глазах в течение четырех часов в городе Иркутске днем убили крестьянина, двух женщин и девушку, последнюю - в пяти шагах от меня, на главной улице», - рассказывал о своем пребывании в городе Э. И. Стогов $[1$, с. 126$]$.

Современники тех событий отмечали, что «в тридцатых годах разбойные нападения на проезжающих по трактам было явление обычное, к которому все привыкли, а разбойничьи шайки были известны населению» ${ }^{5}$. При этом, как правило, имена разбойничьих атаманов отождествляли с той или иной местностью.

Русский этнограф, писатель и фольклорист С. М. Максимов лично посетивший Восточную Сибирь писал, что в середине XIX столетия в окрестностях Иркутска действовал разбойник Гондюхов, около Якутска орудовала шайка Левицкого, а с Забайкальем связывали имена Григорьева и Морозова. Автор утверждал, что «люди эти поставили главной своей целью грабеж на проезжих дорогах и нападение преимущественно на купеческие обозы и казенный транспорт, совершали убийства в таком числе, которое поражало... число убитых достигало в 10-18 душ на каждого разбойника».

«Ограбил кого, следы хорони, не оставляй своего хвоста на дороге, заметай след: ограбленного убивай», - оправдывал свою крайнюю жестокость к потерпевшим известный разбойник и убийца Коренев. Именно в Сибири убийства как вид преступления неразрывно связывались с совершением грабежей и, по мнению С. В. Максимова, являлись их прямым следствием [8, с. 353].

В стремлении к наживе преступники совершали убийства целых семей. Так 30 декабря 1863 г. в Индинской волости Балаганского округа было совершено разбойное нападение на дом инородца Бахана Ванькина. Преступники вначале пытали, а затем зверски убили всю семью Ванькина, состоящую из 5 человек ${ }^{6}$.

Благодаря бытовавшему среди сибиряков мнению о том, что «разбой - промысел легкий и прибыльный, хотя сопряженный с риском» ${ }^{7}$, масштабы грабежей увеличивались с каждым годом. Преступления совершались не только на трактовых дорогах, но и на водных путях.

В корреспонденциях тех лет упоминаются так называемые «байкальские пираты» Буза, Сохатый и Черкаш. По описанию отечественного журналиста Н. А. Полевого эти «буйные удальцы наводили страх и трепет на жителей Иркутска и берегов байкальских... из всех отчаянных голов, которых память осталась в народном предании, никто не страшил столько в свое время, как Буза и Сохатый» [9, с. 264]. Первый продолжительное время грабил богатых армян по берегам Каспийского моря. Будучи схваченным и осужденным на каторгу в Сибирь, бежал и много лет не давал проезда по Ангаре.

До нашего времени дошли скзазания, что «даже мимо Иркутска они проезжали с песнями днем на лодках, одетые в канфенных и штофных куртках и шароваpax, вооруженные винтовками и пистолетами. Всегдашнее становище Бузы было

\footnotetext{
${ }^{4}$ Очерки, рассказы и воспоминания // Русская старина. 1878. XXIII. С. 526.

${ }^{5}$ Разбойник Алифанов // Сибирский архив. 1912. № 4. С. 264.

${ }^{6}$ Первая смертная казнь в Иркутске // Сибирский архив. 1913. № 11. С. 360.

${ }^{7}$ Там же. 1912. № 4. С. 264.
}

\section{Baikal Research Journal}


на берегу Байкала, а главный грабеж - на купеческих судах, переезжающих через Байкал».

Второй, разбойник Сохатый прославился благодаря необыкновенной силе. Н. А. Полевой утверждал, «что он [Сохатый] пришел в Сибирь из пермских лесов, где на душе его, как говорили, легло много убийств и дел ужасных» [9, с. 273]. Известно о его дерзком нападении на Чертовкинскую ярмарку, проводившуюся ежегодно на одном из островов устья Селенги.

В. Птицын рассказывал своим читателям на страницах «Исторического вестника» о том, что «Сохатый во главе 12 товарищей внезапно бросился на балаганы с товарами, захватил, что ему понравилось, и скрылся никем не преследуемый. Такой ужас навело на всех, бывших на ярмарке русских и бурят, - a их было там до 300 человек» [10, с. 237].

При такой активности разбойничьих шаек городской и земской полиции предписывалось «отыскивать виновных, под угрозою лишения места». К борьбе с разбойниками были привлечены воинские команды, а при содействии крестьян производились облавы.

Современники тех событий вспоминали, что «для безопасности проезжающих между станциями ближайшими к городам устраивались пикеты из солдат... где разбойников забирали в плен после боя, при чем с обеих сторон были ушибленные, и раненные, даже убитые. В 1840 году по якутскому тракту в Хомутовой было, например два пикета с 5-6 солдатами».

Помимо облав и пикетов полиция использовала различные оперативные комбинации. По сообщениям местных хроникеров «исправниками придумывалась хитрость к отысканию разбойников и к поимке их». В одних случаях «исправник с солдатами разъезжал в кошевках и разбойники принимали их за своих, вступали с ними в разговоры, а потом при численном превосходстве солдат были забираемы». В других - полиция действовала под видом торговца и когда «разбойники его останавливали неожиданно для них с телег соскакивали десяток вооруженных солдат, а торговец оказывался исправником и - разбойники взяты» ${ }^{8}$.

Между тем известен случай, когда высшему губернскому руководству удалось пресечь деятельность одного из самых грозных атаманов - Даниила Никитича Горкина без проведения масштабных облав и хитроумных комбинаций. Тогда самое непосредственное участие в судьбе разбойника принял генерал-губернатор Восточной Сибири граф Николай Николаевич Муравьев-Амурский.

Среди сибиряков разбойник Д. Н. Горкин слыл грозным и удачливым атаманом, совершившим около 30 разных преступлений, «лицом знаменитым в истории злодейств и известным целой Сибири» [8, с. 183]. Народная молва приписывала опасному преступнику колоссальную силу и небывалую ловкость. Со слов лично знавшего именитого разбойника иркутского священника, протоирея Прокопия Васильевича Громова, «Горкин обладал изумительной силою, это доказал он во дворе... подняв лошадь за передние ноги, как котенка, держал ее в таком положении до тех пор пока коновал окончил свою операцию».

Коренной сибиряк, Горкин родился в 1798 г. в Подгорной деревне, расположенной около Иркутска, и говорил про себя, что к «ремеслу сперва мелких воришков, потом настоящих воров, и наконец, грабителей на дорогах и разбойников приучал их с братом [Иваном] сам [его] злосчастный отец» ${ }^{9}$.

Будучи осужденным за тяжкие преступления, Горкин в первый раз ушел из тюрьмы Кутомарского завода с тремя товарищами. После второго побега он являлся уже атаманом целой разбойничьей шайки, и по рассказам сибиряков,

${ }^{8}$ Сибирский архив. 1912. № 4. С. 264.

${ }^{9}$ Обращение Горкина // Иркутские Епархиальные ведомости. 1869. № 21. С. 274.

\section{Baikal Research Journal}


«появлялся там, где его не ожидают, не боялся шалить и в тех местах, где его стерегут... приобретал друзей из ссыльных, которые успели выйти на поселение и жили своими домами... чем сильнее опасность от преследователей, тем друзья эти находчивей... чем меньше поживы, тем друзья эти деятельней... они наводят на проезжих, указывают на богатых, не задаются набеги - ловко прячут... товарищи делают промахи, излавливаются и гибнут, сам атаман остается цел и невредим» [8, с. 185].

Сохранились свидетельства очевидцев о виртуозной ловкости Горкина при обращении с ручными и ножными кандалами. Дочь декабриста Ольга Аненкова, встречавшаяся с разбойником около Петровского завода, отмечала, что «Горкин обладал особенностью, которая всех приводила в немалое смущение, а именно: когда он встряхивал руками и ногами, оковы спадали с них... простой народ приписывал это сверхъестественным силам. Как говорили, он проделал это раз даже в присутствии генерал-губернатора Восточной Сибири... Броневский, говорят, пришел в ужас» [11, с. 158].

Сам Горкин описывал случай, когда «пришли в тюрьму разные чиновники для снятия допросов, и первое их обращение было такое: «А, злодей, мерзавец! Теперь попался, мы с тобою разделаемся»! Эти злобные слова так меня раздражили, что я тряхнул оковами и крикнул: «Что ж вы пришли издеваться надо мною»? Чиновники перепугались, бросились бежать» ${ }^{10}$.

После очередного побега с каторги Горкин был пойман в Иркутске и водворен в Нерчинские рудники. Опасного преступника не только заковали в ручные и ножные кандалы, но и посадили на короткую цепь.

Однако начальствовавший в то время горный офицер Рик проявил милосердие. По воспоминаниям самого Горкина, когда Рик обратился к нему: «Ну, что если я велю освободить тебя от всех оков, отблагодаришь ли ты меня новым побегом»? Он ответил: «Ваше благородие, если окажите такую милость, тогда ваше сострадание обо мне закрепит меня в заводах надежнее всякого железа» ${ }^{11}$. Горкина освободили, разрешили жениться и построили дом.

Генерал-губернатор Восточной Сибири граф Н. Н. Муравьев-Амурский в 1848 г. при беседе с протоиреем П. В. Громовым услышал историю о встрече священника с разбойничьей шайкой Горкина на р. Алдан. По словам П. В. Громова, «генерал не оставил этого рассказа без внимания, и по возвращении из Камчатки, когда посещал Забайкалье, отыскал Горкина в Нерчинских рудниках, даже оживил его ласковым словом». В последующем граф Н. Н. Муравьев-Амурский беседовал с бывшим разбойником еще несколько раз, и на новоселье Горкина в с. Кабанск подарил ему 10 р. серебром.

Помимо светской власти судьбой бывшего разбойничьего атамана интересовались духовные лица и представители творческой интеллигенции. Епископ Селенгинский, первый викарий Иркутской епархии Вениамин по воспоминаниям современников, «хорошо знал Горкина и, имея пребывание в Посольске близ Кабанска, принимал в нем участие» ${ }^{12}$.

Писатель С. М. Максимов встречался с Горкиным, когда последнего уже перевели в 4-й разряд ссыльных. «Здесь объявилась в нем страсть. Полюбил бойких лошадок, ходил и гладил их и выхолил такую лихую тройку, о которой стали ходить слухи», - вспоминал о преображении некогда грозного разбойника известный этнограф [8, с. 185].

\footnotetext{
${ }^{10}$ Иркутские Епархиальные ведомости. 1869. № 21. С. 269.

11 Там же. С. 271.

12 Там же. С. 267, 273.
}

\section{Baikal Research Journal}

электронный научный журнал Байкальского государственного университета 
По истечении некоторого времени Горкин владел уже несколькими тройками и возил купцов и откупных поверенных из Кабанска через Байкал в Листвиничную.

Скончался Горкин в преклонном возрасте. В метрической книге Харашибирской Вознесенской церкви под № 1 была сделан запись: «1868 г. января 8 дня умер, 10-го погребен Ильинской волости поселенец Даниил Никитин Горкин 70 лет от старости; исповедован и приобщен иереем Николаем Закомельским, похоронен в Хонхолонском селении на общем кладбище» ${ }^{13}$.

Судьба разбойника Горкина являлась исключением из правил. Значительное количество противоправных деяний, сопряженных с грабежом и убийством переводило людей, причастных к преступлениям, в иной разряд. Отношение к таким «особо выдающимся» преступникам со стороны властей было предельно жестоким. Особое значение при этом отводилось решениям высшего губернского руководства ${ }^{14}$. По причине отсутствия в общем правовом поле наказания смертной казнью последние в таких случаях предпочитали руководствоваться нормами военно-уголовного законодательства и разбойников судили военными судами. Казни проводились публично при значительном стечении населения.

В 1913 г. на страницах журнала «Сибирский архив» появилось подробное описание казни, совершенной по решению Иркутского военного суда в 1861 г. над преступниками Кузьминым и Соколовым, осужденными за разбойное нападение и убийство семьи инородца.

Из рассказов очевидцев тех событий известно что, «лобное место было приготовлено за Якутскою заставой, где вкопали в землю два столба». Публичная смертная казнь повлекла большое стечение иркутян. Губернское начальство распорядилось о присутствии на исполнении приговора всех арестантов Иркутского тюремного замка.

Место казни было заранее охвачено войсками. Осужденных привезли на телеге, подвели к лобному месту и сняли кандалы. Бывшие разбойники обошли круг, образованный оцеплением.

«Это было их прощание с миром живых, - писали местные хроникеры, затем преступников провели мимо могил, ожидавших их трупы; они приложились к святому евангелию и кресту... им стали читать смертный приговор. Кузьмин еле держался на ногах, Соколов был бодр и слушал внимательно. Под звуки трубы и барабана их одели в белые саваны, подвели к столбам и привязали веревками. Раздался оружейный залп. Один из расстреливаемых опустил голову, а другой повис почти до земли. Через пулевые отверстия саванов струилась кровь и образовала красные полосы. Через несколько минут трупы, еще теплые сбросили в могилы. Арестанты все время стояли ни живы, ни мертвы, бледны и недвижны» ${ }^{15}$.

Между тем, даже публичные казни не могли отвратить наиболее опасных преступников от совершения грабежей и убийств. «Время от времени подобные выходящие из ряда обыкновенных разбоев преступления производили удручающее действие на общество», - сообщала сибирская пресса ${ }^{16}$. При этом представители власти признавали, что «оказывались совершенно бессильными в деле поимки преступников, так как последние были по большей части вооружены, действовали не в одиночку, а в сообществе, имели лошадей и скрывались в таких местах, где их было трудно выследить и задержать» ${ }^{17}$.

${ }^{13}$ Иркутские Епархиальные ведомости. 1869. № 21. С. 276.

${ }^{14}$ См.: Устав о предупреждении и пресечении преступлении // Свод законов Российской Империи. СПб., 1890. Т. 14. Ст. 288. С. 91.

${ }^{15}$ Сибирский архив. 1913. № 11. С. $361,363$.

${ }^{16}$ Там же. 1912. № 4. С. 265.

${ }^{17}$ ГАИО. Ф. 32. ОП. 1. Д. 4410. Л. 5.

\section{Baikal Research Journal}


Криминальное прошлое многих местных жителей при наличии весомых материальных благ, рожденных повышенной деловой активностью второй половины XIX столетия, неизбежно вело к росту уголовной преступности.

«Дерзость преступников дошла до того, что они производят нападения на прохожих и проезжих не только по проселочным дорогам, но и на Московском тракте среди бела дня, не смотря на постоянное движение по тракту», - докладывал губернатору Иркутский окружной исправник ${ }^{18}$.

К указанному времени преступные группы приобрели более четкую криминальную специализацию и структуру. Увеличение интенсивности товарооборота, осуществлявшегося только посредством гужевого транспорта, привело к появлению хорошо организованных и вооруженных банд, специализировавшихся на грабежах купеческих обозов. Трактовые дороги, по мнению современного исследователя А. В. Данчевской, «ста[новились] отдельным полем для реализации криминальных инициатив» [12, с. 34].

«В начале 80-х годов, - вспоминали сибирские старожилы, по уездам и трактовым дорогам Иркутской губернии не было покоя от разбойных шаек. Они грабили и днем и ночью проезжих, купцов. Хотя для большей безопасности ямщики соединялись по несколько обозов, но от этого пользы было немного, если нападавшие превышали численность обозников. Ямщикам, вооруженным кистенями, приходилось выдерживать нападениями и бои с разбойниками, но пока шла борьба в одном месте, в другом срезались места чая или товаров. Многие богатые возчики, имевшие залог у купцов совсем разорились» ${ }^{19}$.

По смыслу действовавших законов чиновники полиции были должны, «употреблять все возможные способы, стараясь, дабы разбои и грабежи в самом их начале пресечены были» ${ }^{20}$. Однако, прекратить многочисленные нападения в силу хорошей организации преступных действий и особой дерзости исполнителей имеющимися силами, используя обычные способы, не представлялось возможным.

Сибирская пресса сообщала по этому поводу, что в 1881-1882 г. на территории Иркутского округа «было совершенно множество чрезвычайно наглых грабежей и разбоев. Приемы этих грабежей отличались выходящею из ряда дерзостью».

Из показаний потерпевших следовало, что «между участниками грабежей встречались одни и те же лица: при каждом грабеже один из нападавших являлся распорядителем, а предводители шаек атаманы соединяли свои силы для нападения...» ${ }^{21}$.

В таких непростых обстоятельствах по имеющимся инструкциям чиновникам полиции вменялось в обязанности, «узнав о происшедшем в городе или уезде грабеже и разбое, тайно проведывать, кем преступление учинено ${ }^{22}$.

Использование тайных осведомителей позволило установить, что атаманами разбойников являются поселенец Тельминской волости Ефим Бахтиаров, поселенец Черемховской волости Николай Саковский и бегло каторжный Добрынин ${ }^{23}$.

Главным же предводителем шаек пользовавшийся «значением среди разбойников, как главный предводитель шаек» по сведениям полицейских агентов являлся поселенец из каторжных Илгинской волости Федор Алифанов.

Из дошедших до нашего времени сведений невозможно установить, где и когда родился атаман Алифанов. Известно, что вероисповедания он был православ-

\footnotetext{
${ }^{18}$ ГАИО. Ф. 32. ОП. 1. Д. 4410. Л. 4.

${ }^{19}$ Сибирский архив. 1912. № 4. С. 265.

${ }^{20}$ Собрание законов Российской Империи. Т. 14. Ст. 289. С. 91.

${ }^{21}$ Сибирский архив. 1912. № 4. С. 266.

${ }^{22}$ Собрание законов Российской Империи. Т. 14. Ст. 291. С. 92.

${ }^{23}$ ГАИО. Ф. 91. ОП. 1. Д. 1494. Л. 15.
}

\section{Baikal Research Journal}


ного, обладал громадной физической силой, имел интеллигентную наружность с правильными чертами лица и карими глазами, до каторги преподавал в женской гимназии в Таврической губернии.

В 1869 г. Ф. Алифанова осудили за разбой в каторжную работу на 7 лет и 4 месяца. 29 марта 1877 г. по окончании каторги он был уволен от работ в Иркутском солеваренном заводе и причислен на поселение в Илгинскую волость. Имел жену и дочь. Жена - Прасковья Семеновна Алифанова, так же отбыла 5 лет каторжных работ за грабежи и активно содействовала мужу в организации преступлений. С 1882 г. чета Алифановых тайно проживала в Иркутске напротив Кокуевского сада в угловом доме ${ }^{24}$. Сам же атаман, по агентурным сведениям, «отлучался из города только по субботам и воскресениям, а в остальное время бывал дома» ${ }^{25}$.

Именно эта привязанность к семье оказалась фатальной для главного предводителя разбойников. Получив сведения о том, что на территории Рабочей слободы находится «резиденция» бандитов, пристав 2-й полицейской части коллежский acecсор Степан Степанович Романов, по воспоминаниям людей, хорошо знавших эту историю, «решил, во что бы то ни стало поймать Алифанова или быть им убитым».

Вместе со старшим городовым Яковом Кондратьевичем Чусовым, переодевшись в гражданское платье пристав «ходил по разным притонам и прислушивался к разговорам шпаны, в надежде что-нибудь разведать».

Через некоторое время сыскные способности Я. К. Чусова, считавшегося главным специалистом по поимке разбойников, и служебное рвение С.С. Романова, принесли результаты. В одном из питейных заведений полицейские услышали разговор о скором появлении в Знаменском предместье разбойников.

На следующий день пристав распорядился о выставлении на всей территории предместья тайных патрулей и застав. 7 сентября 1882 г. были задержаны члены банды Алифанова - Лебедев и Назаренко. Из последующих докладов полицейских служителей следовало, что «в одну из хибарок по Коштакской улице за Ремесленной слободой заезжала кошевка, запряженная тройкой ухарских лошадей... при расспросах соседи этой хибарки растерялись и просили их не губить» ${ }^{26}$.

Учитывая значение Алифанова в преступной среде, операцию по его задержанию возглавил сам полицмейстер Иркутска майор Константин Андреевич Тягунов.

В 2 часа дня 20 ноября в дом поселенца Илгинской волости Павла Егоровича Лунева вошли полицмейстер К. А. Тягунов, пристав С. С. Романов, городовой Я. К. Чусов, казаки Иркутской сотни А. Нефедьев и К. Кочин. Полицейских встретил рослый широкоплечий мужчина.

«Нам известно, что вы Алифанов, мы пришли вас арестовать» - обратился к преступнику К. А. Тягунов. Алифанов ответил, что сдается лично полицмейстеру, «но взять силой и вязать себя не позволит» ${ }^{27}$. Дальнейшие события показали, что заявление разбойника о добровольной сдаче были лишь уловкой.

Ф. Алифанов все-таки оказал активное сопротивление. По свидетельству К. А. Тягунова, «он свалил Я. К. Чусова, порываясь достать его лицо зубами, несколько раз хватался за рукоятки казацких шашек и пытался вытаскивать их из ножен» .

Решив, что в помещении связать Алифанова не получится, полицейские вытащили рассвирепевшего разбойника во двор. Однако и там, уже, будучи связанным,

\footnotetext{
${ }^{24}$ ГАИО. Ф. 91. ОП. 1. Д. 1494. Л. 10.

${ }^{25}$ Там же. Л. 8.

${ }^{26}$ Сибирский архив. 1912. № 4. С. $266,268$.

${ }^{27}$ ГАИО. Ф. 91 . ОП. 1. Д. 1494. Л. 17.
}

\section{Baikal Research Journal}


Алифанов сумел вынуть из-за голенища складной нож. Лишь спустя некоторое время и с большими усилиями полицейским удалось отобрать нож. После чего связанного разбойника уложили в сани и отправили в Иркутский тюремный замок.

При обыске у Алифанова изъяли: серебряные вызолоченные часы № 26 621, шестиствольный револьвер № 363 в кобуре и одно заряженное двуствольное ружье. Главная же улика - деньги были обнаружены у Прасковьи Алифановой. Узкий продолговатый мешочек с зашитыми девятью сторублевыми ассигнациями жена разбойника прятала в своей косе.

Вскоре после этого задержали еще двух членов разбойничьей шайки - Ефима Бахтиарова и Николая Саковского. Началось следствие, тянувшееся более года. Стремясь уйти от возмездия, Алифанов попытался бежать. В ночь на 11 февраля 1884 г. он «разобрал потолок своей камеры, крышу и по веревке, сделанной в течении года из арестантских тюфяков, спустился по стене на землю, но тут был схвачен часовым» [13, с. 95].

В марте 1884 г. состоялся военный суд, признавший виновными: Ф. Алифанова - в 4 кражах, 4 разбойных нападениях и 4 вооруженных сопротивлениях; Е. Бахтиарова - в 3 разбойных нападениях, произведенных с особым зверством; Н. Саковского - в 5 разбойных нападениях. Подсудимых приговорили к смертной казни через повешение. Приговор привели в исполнение во дворе пересыльного замка 24 марта 1884 г. $^{28}$

Так была пресечена деятельность одной из многочисленных банд, действовавших на территории Иркутской губернии в конце XIX в. К указанному времени большая часть разбойных нападений на торговых путях и около административных центров края совершалась группами профессиональных преступников, сплоченных около криминальных лидеров - атаманов, доминировавших над прочими благодаря высоким физическим и волевым качествам.

Первые сведения о появлении близ Иркутска разбойничьих шаек появились в конце XVIII столетия. Увеличение темпов штрафной колонизации привело к сплочению ссылаемых преступников в группы. Разбойники действовали около населенных пунктов и на трактовых путях, расположенных близ каторжных заводов и рудников.

Немаловажным фактором, усугублявшим положение, являлось то, что ссылаемые преступники уже обладали знаниями и умениями в определенных отраслях криминального ремесла. Таким образом, благодаря особенностям пенитенциарной политики самодержавия, в крае с минимальной плотностью населения и фактическим отсутствием промышленных центров появились предпосылки к формированию устойчивых групп профессиональных преступников.

Отсутствие легитимных возможностей пресечения деятельности разбойничьих шаек обуславливало стремление губернской администрации к использованию внесудебных форм расправы. Однако репрессивные меры не приносили положительных результатов, и со временем действия преступников приобретали большие масштабы и крайне жестокие формы.

К середине XIX столетия решение проблемы противодействия разбойным нападениям, совершаемым устойчивыми группами преступников, потребовало применение чрезвычайных мер. Власти привлекали воинские подразделения, использовали нормы военно-уголовного законодательства и совершали публичные исполнения смертных приговоров.

Высокая концентрация профессиональных преступников в определенных районах, их поддержка частью местного населения и возможность получения весо-

${ }^{28}$ ГАИО. Ф. 91. ОП. 1. Д. 1582. Л. 16.

\section{Baikal Research Journal}

электронный научный журнал Байкальского государственного университета 
мых материальных благ от криминального промысла способствовали образованию устойчивых групп. Жестокие наказания, налагаемые в одних случаях без судебных решений, в других решениями военных судов обуславливали стремление преступников к скрытности и устранению свидетелей. Вследствие чего в преступной среде совершение грабежей неразрывно связывалось с убийствами потерпевших. Явное несоответствие полицейских возможностей объемам и характеру преступных деяний оставляли большую их часть без наказания. Все вместе взятое предопределило появление на территории Иркутской губернии в начале XX столетия грабительских организаций.

\section{Список использованной литературы}

1. Дамешек И. Л. Окраинная политика России в первой половине XIX в. (на примере Восточной Сибири) : дис. ... канд. ист. наук : 07.00 .02 / И. Л. Дамешек. - Иркутск : Издво Иркут. гос. ун-та, 1998. -275 с.

2. Марголис А. Д. О численности и размещении ссыльных в Сибири в конце XIX в. / А. Д. Марголис // Ссылка и каторга в Сибири (XVIII - начала XX вв.) : сб. ст. / под ред. А. М. Горюшкина. - Новосибирск : Наука, 1975. - С. 223-238.

3. Калашников И. Т. Записки иркутского жителя / И. Т. Калашников // Русская старина. - 1905. - № 123. - С. 187-251.

4. Пежемский П. И. Иркутская летопись / П. И. Пежемский, В. А. Кротов ; предисл. и примеч. И. И. Серебряникова. - Иркутск : Тип. и лит. И. П. Казанцева, 1911. - 418 с.

5. Андриевич В. К. Сибирь в ХІХ столетии : в 2 ч. / В. К. Андриевич. - СПб. : Тип. и лит. В. В. Комарова, 1889. - Ч. 1 : Период от смерти Императрицы Екатерины II до 1806 г. -298 c.

6. Стогов Э. И. Записки жандармского штаб-офицера эпохи Николая I / Э. И. Стогов. - М. : Индрик, 2003. - 240 с.

7. Андриевич В. К. Сибирь в ХІХ столетии : в 2 ч. / В. К. Андриевич. - СПб. : Тип. и лит. В. В. Комарова, 1889. - Часть 2 : Период с 1806 по 1819 г. - 425 с.

8. Максимов С. В. Сибирь и каторга : в 3 ч. / С. В. Максимов. - СПб. : Тип. А. Траншеля, 1871. - $353 \mathrm{c}$.

9. Полевой Н. А. Сохатый / Н. А. Полевой // Денница. Альманах на 1830 год / изд. М. Максимович. - СПб., 1830. - С. 261-278.

10. Птицын В. Забайкальские разбойники / В. Птицын // Исторический вестник. 1890. - № 4. - C. 237-241.

11. Анненкова П. Е. Воспоминания Полины Анненковой : с прил. воспоминаний ее дочери О. И. Ивановой и материалов из архива Анненковых / П. Е. Анненкова ; предисл. и примеч. С. Гессена, Ан. Предтеченского. - 2-е изд. - М. : Изд-во политкаторжан, 1932. - $356 \mathrm{c}$.

12. Данчевская А. В. Уголовная преступность на трактах Восточной Сибири в конце XIX начале - XX веков / А. В. Данчевская // Актуальные вопросы развития современного общества : сб. науч. ст. по материалам 1-й Междунар. науч.-практ. конф. - Пермь : Изд-во ИП Сигитова, 2016. - С. 32-35.

13. Романов Н. С. Летопись города Иркутска за 1881-1901гг. / Н. С. Романов. - Иркутск : Вост.-Сиб. кн. изд-во, 1993. - 544 с.

\section{References}

1. Dameshek I. L. Okrainnaya politika Rossii v pervoi polovine XIX v. (na primere Vostochnoi Sibiri). Kand. Diss. [Russia's marginal policy in the first half of XIX century (in terms of East Siberia). Cand. Diss.]. Irkutsk State University Publ., 1998. 275 p.

2. Margolis A. D. On number and settlement of the exiled in Siberia in late 19 century. In Goryushkin A. M. (ed.). Ssylka i katorga v Sibiri (XVIII - nachala XX vv.) [Exile and labor in Siberia (17 - early 20 century)]. Novosibirsk, Nauka Publ., 1975, pp. 223-238. (In Russian).

3. Kalashnikov I. T. Memoirs of an Irkutsk citizen. Russkaya starina $=$ The Russian Olden Time, 1905, no. 123, pp. 187-251. (In Russian).

\section{Baikal Research Journal}


4. Pezhemsky P. I., Krotov V. A. Irkutskaya letopis' [The Irkutsk Chronicle]. Irkutsk, I. P. Kazantsev Publ., 1911. 418 p.

5. Andriyevich V. K. Sibir' $v$ XIX stoletii [Siberia in the $19^{\text {th }}$ century]. Saint Petersburg, V. V. Komarov Publ., 1889. Pr. 1. 298 p.

6. Stogov E. I. Zapiski zhandarmskogo shtab-ofitsera epokhi Nikolaya I [Memoirs of a gendarme field officer of the Nicolas I epoch]. Moscow, Indrik Publ., 2003. 240 p.

7. Andriyevich V. K. Sibir' $v$ XIX stoletii [Siberia in the $19^{\text {th }}$ century]. Saint Petersburg, V. V. Komarov Publ., 1889. Pr. 2. 425 p.

8. Maksimov S. V. Sibir' i katorga [Siberia and hard labor]. Saint Petersburg, A. Transhel' Publ., 1871. 353 p.

9. Polevoy N. A. The Elk. In Maksimovich M. (ed.). Dennitsa. Al'manakh na 1830 god [The Daybreak. Almanac for the year of 1830]. Saint Petersburg, 1830, pp. 261-278. (In Russian).

10. Ptitsyn V. The Transbaikal Robbers. Istoricheskii vestnik = Historical Bulletin, 1890, no. 4, pp. 237-241. (In Russian).

11. Annenkova P. E.; Gessen S., Predtechenskii An. (eds). Vospominaniya Poliny Annenkovoi [Memoirs of Polina Annenkova]. $2^{\text {nd }}$ ed. Moscow, Political Convicts' Publishing House, 1932. $356 \mathrm{p}$.

12. Danchevskaya A. V. Criminal activities on the roads of East-Siberia in late 19 - early 20 centuries. Aktual'nye voprosy razvitiya sovre-mennogo obshchestva. Materialy 1-i Mezhdunarodnoi nauchno-prakticheskoi konferentsii [Topical issues of present-day society's development. Materials of the 1st International Research Conference]. Perm, Sigitov Publ., 2016, pp. 32-35. (In Russian).

13. Romanov N. S. Letopis' goroda Irkutska za 1881-1901 gg. [Chronicle of Irkutsk Town over the period of 1881]. Irkutsk, East-Siberian Book Publisher, 1993. 544 p.

\section{Информация об авторах}

Сысоев Алексей Александрович - доцент, кафедра тактико-специальной и огневой подготовки, Восточно-Сибирский институт МВД России, 664074, г. Иркутск, ул. Лермонтова, 110, e-mail: daoss@pochta.ru.

Кавецкий Длитрий Борисович - старший преподаватель, кафедра тактико-специальной и огневой подготовки, Восточно-Сибирский институт МВД России, 664074, г. Иркутск, ул. Лермонтова, 110, e-mail: kadmi68@mail.ru.

\section{Authors}

Aleksey A. Sysoyev - Associate Professor, Chair of Tactical-Special and Weapons Training, East-Siberian Institute of the MIA of Russia, 110 Lermontov St., 664074, Irkutsk, Russian Federation; e-mail: daoss@pochta.ru.

Dmitry B. Kavetsky - Senior Lecturer, Chair of Tactical-Special and Weapons Training, East-Siberian Institute of the MIA of Russia, 110 Lermontov St., 664074, Irkutsk, Russian Federation; e-mail: kadmi68@mail.ru.

\section{Библиографическое описание статьи}

Сысоев А. А. Устойчивые преступные группы и их преследование на территории Иркутской губернии в XIX столетии / А. А. Сысоев, Д. Б. Кавецкий // Baikal Research Journal. — 2017. - T. 8, № 2. — DOI: 10.17150/2411-6262.2017.8(2).4.

\section{Reference to article}

Sysoyev A. A., Kavetsky D. B. Stable criminal groups and their pursuit on the territory of Irkutsk Province in the XIX century. Baikal Research Journal, 2017, vol. 8, no. 2. DOI: 10.17150/2411-6262.2017.8(2).4. (In Russian).

\section{Baikal Research Journal}

